\title{
How Difficult Google Classroom Is? A Case Study of Blended Learning Method in Physical Education
}

\author{
Dony Tirta Hendriansyah ${ }^{1}$, Billy Castyana ${ }^{2}$, Tandiyo Rahayu ${ }^{3}$, Mohammad Arif $\mathrm{Ali}^{4}$, \\ Gustiana Mega Anggita ${ }^{5}$ \\ \{donytirtah@gmail.com ${ }^{1}$, billycastyana@mail.unnes.ac.id ${ }^{2}$, tandiyorahayu@ mail.unnes.ac.id ${ }^{3}$ \} \\ Universitas Negeri Semarang, Semarang, Indonesia ${ }^{1,2,3,4,5}$
}

\begin{abstract}
The aim of this study was to determine the difficulty of using Google Classroom as media of the physical education learning. This quantitative descriptive research used 4-points likert survey and interview methods with indicators of ease to access, ease to operate, suitable for users, suitable for learning, and effectiveness in learning. Research conducted on 133 high school students in Semarang showed that $93.23 \%$ stated Google Classroom helped physical education learning. However, many students still complained about the difficulties in accessing the application due to internet signal. Therefore, it is important to provide new applications that can be accessed and operated offline and online so that physical education learning with blended learning methods can be carried out in all areas even though they do not yet have good internet access.
\end{abstract}

Keywords: Blended Learning, Physical Education, Google Classroom.

\section{Introduction}

In a pandemic like today, the use of technology cannot be separated from human life. So many benefits can be felt as a result of the use of technology in human life that they can increase productivity quickly, precisely, and accurately [1]. However, not all use of technology has a positive impact because with easy access for everyone can also lead to negative impacts [2]. Even so, the use of technology can help in the Covid-19 pandemic era, especially in physical education learning through the Blended Learning method.

Blended Learning method which is a combination of face-to-face and online methods [3] has been widely used in universities for the past decade [4]. In another study it was mentioned that Blended Learning is a unity between traditional learning that is face to face with the written communication that exists in online learning [5]. This makes Blended Learning a flexible method [6]. The research results of Vernadakis et al (2011) also showed that students who took classes with the blended learning method showed higher scores compared to those who attend face-to-face classes only [7]. This is also in line with what was said by Gomez and Igado who stated that web-based education, especially blended learning, has the ability to strengthen the core of teaching and learning so it could make students learn better [8].

Learning with this method also has various advantages [9] including students being able to improve independent learning because all material is available online. In addition, this 
method can create good communication between teachers and students, fellow students, and finally be able to control learning even if it is done outside of class hours. With online media, teachers are also made easy to conduct assessments, provide feedback, and manage test results effectively and efficiently. By using an online system, this method requires media that can accommodate teachers and students, one of which is Google Classroom.

Google Classroom is a useful media to improve learning systems because this media helps teachers organize classes and improve communication between teachers and students [10]. The system created by Google in 2016, only takes six months to make it a system that is used in the wider world of education. A study found that students prefer to learn to use Google Classroom where teachers have a more passive rather than active role [11]. This system also encourages teachers to create and collect assignments from students without the need to use paper, so it is environmentally friendly. This system even allows teachers to focus more on the development of students rather than having to struggle with the correction of assignments on paper, because this system has the ability to correct and provide grades directly [10].

There are several benefits of using Google Classroom [12], including systems that are designed in a simple way so that they are easy to use. Google Classroom is also designed automatically and integrated with other Google applications, so it can save time. Currently, it has more professional technology related to communication because this system already uses cloud-based enterprise communications tools that are often used by professional workers so that it is easy to access and can be used as a learning medium, both in learning that requires face-to-face or on learning that uses the full online system. In addition, Google Classroom is also designed to be used not only by using a laptop or notebook media, but also can be accessed via a mobile phone.

In addition to what has been said above, other research also mentioned several benefits of Google Classroom [13], such as the use of Google Classroom for streaming counseling. In addition, Google Classroom is also able to facilitate collaborative learning where teachers can upload learning materials and students can provide feedback by giving comments, and vice versa [14]. It was able to assist teachers in organizing classrooms and can communicate efficiently with students [15]. This media also can improve students' cognitive abilities by making classes into student-centred learning even in previous studies showing students feel comfortable using this media and can also be applied to other subjects, one of them is physical education.

Physical education becomes important to be associated with Blended Learning because of its role can develop abilities and shape the character of students so they are able to develop their potential [16]. It also can improve physical fitness, develop motor skills, teach to have healthy living behaviors, be sporty, and increase emotional intelligence [17]. This learning has goals that focus on increasing intellectual behavior, such as developing knowledge and understanding thinking skills [18]. This can be achieved when learners fulfill the two essentials of physical education, namely the nature of learning and the nature of physical education [16]. The nature of learning is not only about teaching and transferring knowledge from teachers to students, this nature is able to open opportunities for teachers to maximize the potential of students so that they can become independent human beings [10]. The second nature is the nature of physical education, where this nature discusses how humans can move and want to move. For humans, moving has several factors that affect, among others, the physical abilities of students, their ability to move, a feeling of security to carry out activities, perceptual abilities, and emotional intelligence [19]. These factors must be considered by teachers so that physical education goals can be achieved. 
However, the learning objectives will not be achieved if the students do not have enough time to actively move so that the quality of fitness is good. This happens because of the lack of study hours given for physical education so that there needs to be a solution that is by applying the Blended Learning method with Google Classroom media. Because the application of Blended Learning can improve the quality of learning by showing changes in student outcomes, learning motivation, and interest for the better [6] [20] [21]. Unfortunately, the use of Google Classroom media in physical education learning has only been fully applied in the Covid-19 pandemic era. Not yet known the extent of the difficulty of this media. Therefore, research was conducted to determine the level of difficulty of using Google Classroom media on physical education.

\section{Methods}

This type of quantitative research uses descriptive research design to determine the difficulty level of students in using Google Classroom as an online media for blended learning. This research was conducted as part of research on the application of the blended learning method to physical education in high school and in the process, the teacher used Google Classroom media for the learning process. The selection of high school as a research object because the application of the blended learning method in physical education is something new, thus this learning requires an understanding of to use technology and high school students are familiar with it. The population in this study was high school in Semarang and in taking the sample, researcher used a purposive sampling technique with the criteria of a school that had implemented the K-13 curriculum, where the school have three hour credits of physical education subject.

Before carrying out data retrieval, the teachers were asked to carry out learning using the Blended Learning method with Google Classroom media for three months. Teachers gave different material, such as Futsal, Handball, Basketball, Badminton, Volleyball, Sepak Takraw, and Track and Field, involving three different classes. The material is learning material contained in the high school curriculum of the Ministry of Education and Culture. In addition, the selection of the class was because each material was not taught at the same grade so three classes were selected to study the material and the teacher was asked to apply the blended learning method to teach the material.

After all students have tried the methods, they were asked to fill in a 4-scale Likert instrument which contains four indicators, i.e. Ease to Access, Ease to Operate, Suitable for users, Suitable for learning, and Effectiveness in learning. Then the data were analyzed using percentages to see the level of difficulty in using Google Classroom media on the Blended Learning method.

\section{$3 \quad$ Results and discussion}

\subsection{Results}

Demography. In this study, there were 133 respondents who came from high school students in Semarang. The respondents have age demographics, namely respondents aged 15 years 24 people or $18.05 \%$, age 16 years 77 people or $57.89 \%$, and age 17 years 32 people or 
$24.06 \%$. In addition, when viewed by sex, the number of male respondents was 48 people or $36.09 \%$ and female respondents were 85 people or $63.91 \%$.

Difficulty Level. Based on the results of data analysis, it can be seen that $93.23 \%$ of respondents said Google Classroom is easy to use for physical education learning.

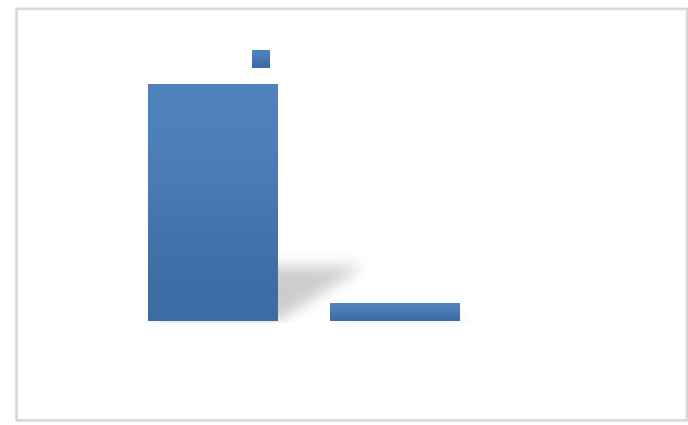

Fig. 1. Difficulty Level of Google Classroom

However, if viewe from the results of the analysis per indicator, it can be seen that only $67.67 \%$ of respondents feel that Google Classroom is suitable for users.

Table 1. Data of each indicators.

\begin{tabular}{lcc}
\hline Indicators & Agree (\%) & Disagree (\%) \\
\hline Ease to Access & 92,29 & 7.71 \\
Ease to Operate & 94.36 & 5.64 \\
Suitability for users & 67.67 & 32.33 \\
Suitability for learning & 91.28 & 8.72 \\
Effectiveness in learning & 85.09 & 14.91 \\
\hline
\end{tabular}

\subsection{Discussion}

Google Classroom is part of the online Google Apps for Education (GAFE), where this application is designed for online learning. Although users can download it for free and integrate with other Google applications, such as Gmail, Google Calendar, and Google Drive, but this application can only be used in educational institutions. This makes many teachers lazy to use it because of the lack of information provided. Though this application offers various facilities, ranging from the ease in sending information between teachers and students and between students, interactive discussions, to the distribution and collection of assignments [14].

How to Use Google Classroom. Google classroom is an application that can be downloaded via Playstore and Appstore on mobile or can be accessed via classroom.google.com. After the teacher and student download or access this system, the teacher and student can immediately log in using their email address (gmail). 


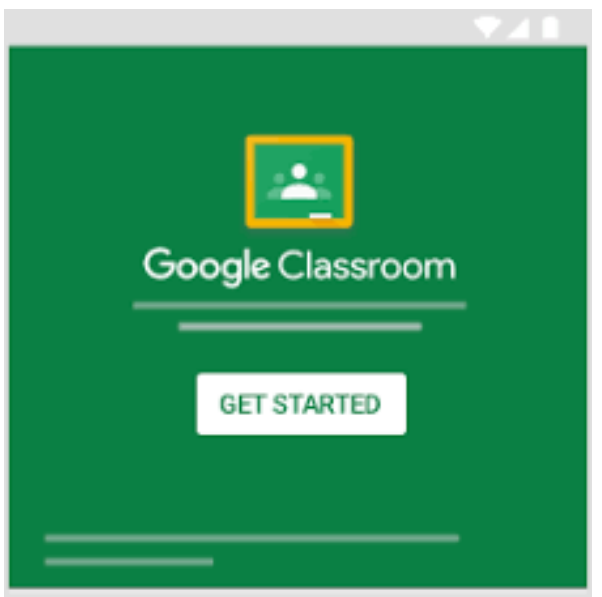

Fig. 2. Google classroom started page on mobile phone

After entering the Google Classroom application the teacher can press the button with a "+" sign. Then, two options appear, i.e. join the existing class or create a new class.

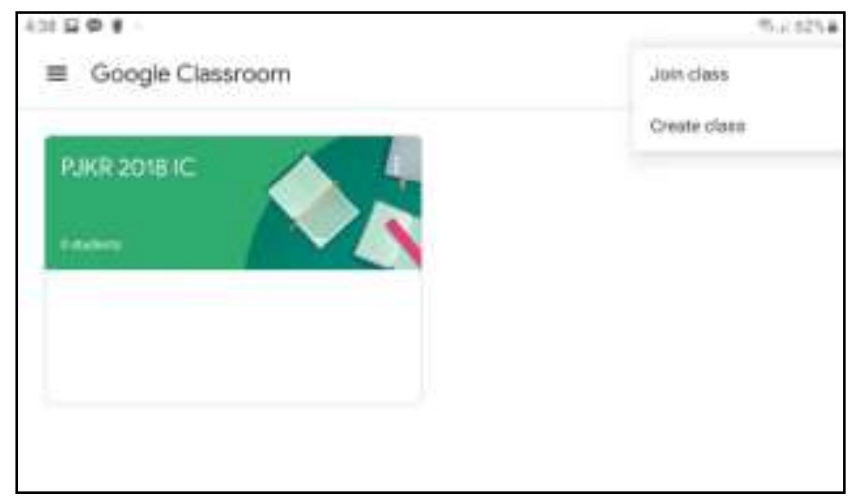

Fig. 3. Create classes in google classroom

Later, if the teacher wants to create a new class, then the teacher must fill in the class name and subjects to be taught. Whereas students can choose the option to join classes that have been available through invitations sent by the teacher or enter the class code.

Obstacles on Google Classroom. The use of Google Classroom for some users in Indonesia still has many obstacles, one of which is limited internet access. This is what causes the still high level of difficulty in using these online-based media. Most of the students who were respondents stated that when they access Google Classroom they need a large amount of data and most rely on wifi at school. This finally makes students unable to study independently by using Google Classroom. Although Indonesia is currently showing significant internet development, where there are more than $28 \%$ of the total population in Indonesia using the inter- 
net $^{23}$, but this has not reached all regions. According to the report, Indonesia's Internet penetration rate is $21 \%$ with an increase of $20 \%$ over the past decade [22].

Using Google Classroom on Physical Education. In physical education classes, Google Classroom becomes the media to provide theoretical material to students. Later the teacher can upload video material that has been made by the teacher or the teacher can search for video material from YouTube then upload it to the class. The students can later see and study the video wherever and whenever before the material is practiced in class.

In order to be able to see progress and also monitor the learning process of students, teachers can discuss about the material with students through the comments column. In addition, teachers can also give assignments and theoretical tests through applications that are integrated in Google Classroom, such as Google Doc, etc.

In addition, students can also upload videos of the movements made when practicing the material in school and later the teacher can assign other students to analyze the mistakes made and how to correct techniques. This is an important part of the basic curriculum of Physical Education, where students must be able to develop their cognitive abilities through analysis. The teacher can also provide input to students through the comments column and students can improve their movements at the next meeting.

If we see from how the explanation of the implementation of Google Classroom in physical education subjects above, then we can know that this media can help teachers maximize the time of physical education subjects to make students move. Media, in turn, does not replace the function of the teacher to provide material, because teachers are required to be creative and develop various learning media so that students are not bored. This media makes learning patterns not only teacher-centered but student-centered.

\section{Conclusion}

Google Classroom is an application that has been around for a long time but its application is still not optimal, especially in physical education subjects. Yet through this application, teachers and students can interact with each other directly wherever and whenever. So learning theory in physical education subjects can be maximized through the Blended Learning method with Google Classroom media. Because through the Google Classroom media students can further explore their critical thinking skills and support to reduce the use of paper in the school environment.

For teachers too, this media can help to save time in conveying material in theory and make corrections to assignments given to students. This can maximize the time of physical education subjects to make students move so that they can meet the objectives of physical education.

In terms of its use which is still based on internet access, it is expected that there will be development platforms such as Google Classroom that can be used offline and online, especially for physical education. This will greatly help teachers and students, especially those in remote areas and who do not have good internet access, to be able to develop Blended Learning methods widely throughout Indonesia.

\section{References}

[1] W. Wardiana, Perkembangan teknologi informasi di Indonesia. 2002. 
[2] S. Ameliola, Nugraha, and D. Hanggara, "Perkembangan media informasi dan teknologi terhadap anak dalam era globalisasi," in Prosiding In International Conference On Indonesian Studies" Ethnicity And Globalization, 2013.

[3] M. Giannousi, "A Comparison of Student Knowledge between Traditional and Blended Instruction in a Physical Education in Early Childhood Course," Turkish Online J. Distance Educ., vol. 15, no. 1, pp. 99-113, 2014.

[4] P. Ginns, M. Prosser, and S. Barrie, "Students' perceptions of teaching quality in higher education: The perspective of currently enrolled students," Stud. High. Educ., vol. 32, no. 5, pp. 603-615, 2007.

[5] D. Garrison, Randy, and N. D. VAUGHAN, Blended learning in higher education: Framework, principles, and guidelines. John Wiley \& Sons, 2008.

[6] I. Syarif, "Pengaruh model blended learning terhadap motivasi dan prestasi belajar siswa SMK," J. Pendidik. Vokasi, vol. 2, no. 2, 2012.

[7] N. Vernadakis, "The impact of blended and traditional instruction in students' performance," Procedia Technol., vol. 1, pp. 439-443, 2012.

[8] J. Gomez and M. Igado, "Blended learning: The key to success in a training company," Int. J. Instr. Technol. Distance Learn., vol. 5, no. 8, pp. 33-42, 2008.

[9] H. Husamah, "Pembelajaran bauran (Blended learning)," Res. Rep., 2014.

[10] A. Harefa, Menjadi manusia pembelajar: Pemberdayaan diri, transformasi organisasi dan masyarakat lewat proses pembelajaran: menuju Indonesia 2045. Harian Kompas, 2000.

[11] S. Iftakhar, "Google classroom: what works and how," J. Educ. Soc. Sci., vol. 3, no. 1, pp. 12-18, 2016.

[12] R. A. S. Al-Maroof and M. Al-Emran, "Students acceptance of Google classroom: An exploratory study using PLS-SEM approach,” Int. J. Emerg. Technol. Learn., vol. 13, no. 06, pp. 112-123, 2018.

[13] M. JANZEN, "Hot Team: Google Classroom," 2014, [Online]. Available: tlt. psu.edu.

[14] A. Keeler and L. Miller, 50 Things You Can Do with Google Classroom. Dave Burgess Consulting, 2015.

[15] M. Shaharanee, I. Nizal, J. JAMIL, M. Rodzi, and S. Syamimi, "The application of Google Classroom as a tool for teaching and learning," J. Telecommun. Electron. Comput. Eng., vol. 8, no. 10, pp. 5-8, 2016.

[16] A. Rithaudin and I. P. T. P. Sari, "Analisis pembelajaran aspek kognitif materi pendidikan jasmani olahraga dan kesehatan sma/smk di Daerah Istimewa Yogyakarta.," J. Pendidik. Jasm. Indones., vol. 15 , no. 1 , pp. 33-40, 2019.

[19] S. KUSAIRI, "Pengaruh blended learning terhadap penguasaan konsep dan penalaran fisika peserta didik kelas X," J. Pendidik. Fis. Indones., vol. 9, no. 1, 2013.

[20] S. B. Sjukur, "Pengaruh blended learning terhadap motivasi belajar dan hasil belajar siswa di tingkat SMK," J. Pendidik. vokasi, vol. 2, no. 3, 2012.

[21] A. Abdullah and A. Manadji, Dasar-dasar Pendidikan Jasmani. Jakarta: Departemen Pendidikan dan Kebudayaan., 1994

[22]A. Baidhori, "PEMBELAJARAN PENDIDIKAN JASMANI BERBASIS BLENDED LEARNING," in Seminar Nasional Pendidikan Olahraga, 2017, pp. 242-250.

[23] P. Setyosari, Ranah Kognitif dalam Pembelajaran. Malang: Unmal, 2013.

[24] S. Sujarwoto and G. Tampubolon, "Spatial inequality and the Internet divide in Indonesia 20102012,” Telecomm. Policy, vol. 40, no. 7, pp. 602-616, 2016. 